\title{
Drought and Associated Impacts in the Great Plains of the United States-A Review
}

\author{
Jeffrey B. Basara ${ }^{1,2 *}$, Joanna N. Maybourn ${ }^{1,3}$, Casey M. Peirano ${ }^{1}$, Jennifer E. Tate ${ }^{1}$, \\ Parker J. Brown ${ }^{1}$, Jake D. Hoey ${ }^{1}$, Brandon R. Smith ${ }^{1}$ \\ ${ }^{1}$ School of Meteorology, University of Oklahoma, Norman, USA \\ ${ }^{2}$ Oklahoma Climatological Survey, University of Oklahoma, Norman, USA \\ ${ }^{3}$ University of Reading, Reading, UK \\ Email: *jbasara@ou.edu, Joanna.N.Maybourn-1@ou.edu, cpeirano@ou.edu,jenni4t8@ou.edu, \\ parker.brown@ou.edu, Jake.D.Hoey-1@ou.edu, Brandon.R.Smith-1@ou.edu
}

Received June 3, 2013; revised July 5, 2013; accepted August 1, 2013

Copyright (C) 2013 Jeffrey B. Basara et al. This is an open access article distributed under the Creative Commons Attribution License, which permits unrestricted use, distribution, and reproduction in any medium, provided the original work is properly cited.

\begin{abstract}
The Great Plains region of the United States is susceptible to drought of all kinds including meteorological/climatological, agricultural, hydrological, and socioeconomic. Drought conditions in the region span varying spatial and temporal scales and the causes include: 1) certain synoptic conditions that favor drought such as mid-tropospheric ridging over the drought-affected area and a weak low-level jet; 2) sea surface temperature anomalies and associated teleconnections; 3) land-atmosphere coupling; and 4) anthropogenic effects. While drought can span as few as a couple of months, the most severe droughts can occur at the decadal scale such as the 1930s Dust Bowl, the worst drought in recent history from a societal standpoint. Such droughts in the Great Plains have widespread impacts on agriculture, water resources, human health, and the economy.
\end{abstract}

Keywords: Drought; Great Plains; United States; Rainfall; Precipitation

\section{Introduction}

The Great Plains of North America span a region from the Gulf of Mexico in the south to the coniferous forests of Canada to the north and are bordered on the west by the Rocky Mountains. These Plains spread east approximately $1000 \mathrm{~km}$ into the interior regions of North America along an east-west oriented precipitation gradient with annual values over 70 in (over $1800 \mathrm{~mm}$ ) to the east and less than 12 in (less than $300 \mathrm{~mm}$ ) to the west (Figure 1). At the same time, the region is also defined by a north-south oriented temperature gradient (Figure 2). The orthogonal nature of the temperature and precipitation gradients yield significant biodiversity across relatively short distances within the Great Plains region. At the same time, because the gradient of precipitation is large across the region, multiple environmental factors can lead to significant variability in temperature and precipitation at periods spanning seasonal, to interannual, to decadal scales. Figures $\mathbf{3}$ and $\mathbf{4}$ display the temperature and precipitation trends for the National Oceanic and Atmospheric Administration (NOAA) domain that re-

*Corresponding author. presents the Oklahoma Panhandle region in northwest Oklahoma (Oklahoma Climate Division 1). Over the period spanning more than a century, significant interannual variability has existed superimposed on decadal scale trends of above normal precipitation (pluvials) and below normal precipitation (drought).

The Great Plains, specifically within the United States (US), have experienced drought conditions at multiple spatial and temporal scales. The most infamous drought was the Dust Bowl of the 1930s (e.g., Figures 3-4) because of its intensity, duration, devastating economic impacts, iconic dust storm images, and significant social migration [1,2]. In addition, the decade of the 1950s experienced extreme drought conditions [2]. However, during the drought of the 1950s (e.g., Figures 3-4), the societal impacts were muted by growing awareness and mitigation strategies employed following the Dust Bowl years which included more sustainable farming practices focused on preventing soil erosion. Thus, while in many areas of the Great Plains the meteorological drought was worse during the 1950s than the 1930s (hotter and drier) and such practices helped to reduce the socioeconomic impacts across the region. 


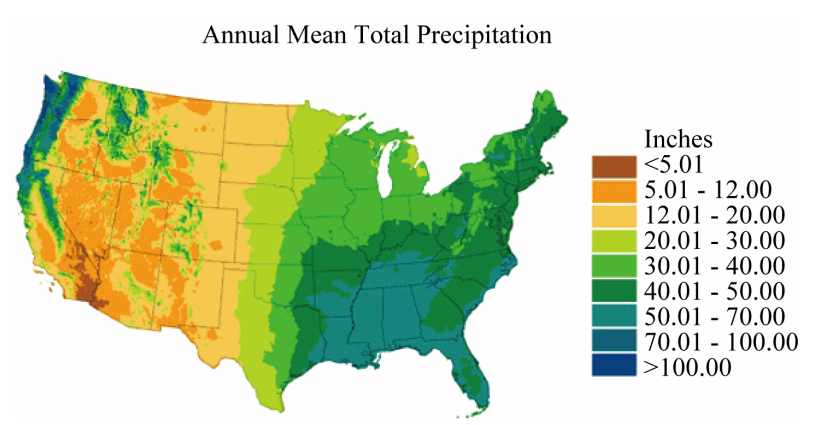

Figure 1. Annual total precipitation (in) across the contiguous United States (source the NOAA Climate Atlas of the United States).

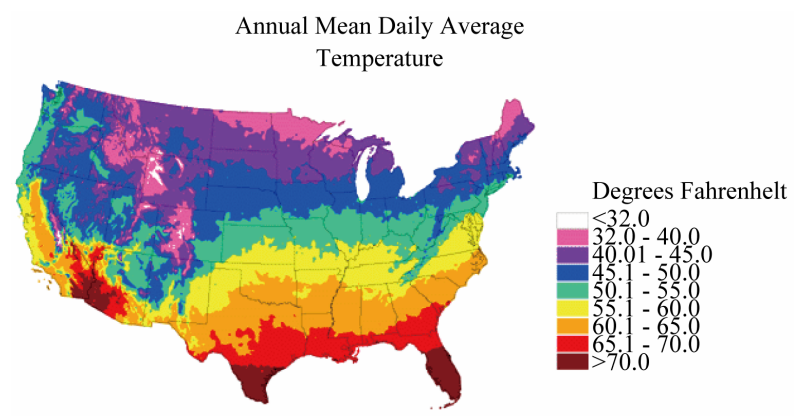

Figure 2. Annual mean daily average temperature $\left({ }^{\circ} \mathrm{F}\right)$ across the contiguous United States (source the NOAA Climate Atlas of the United States).

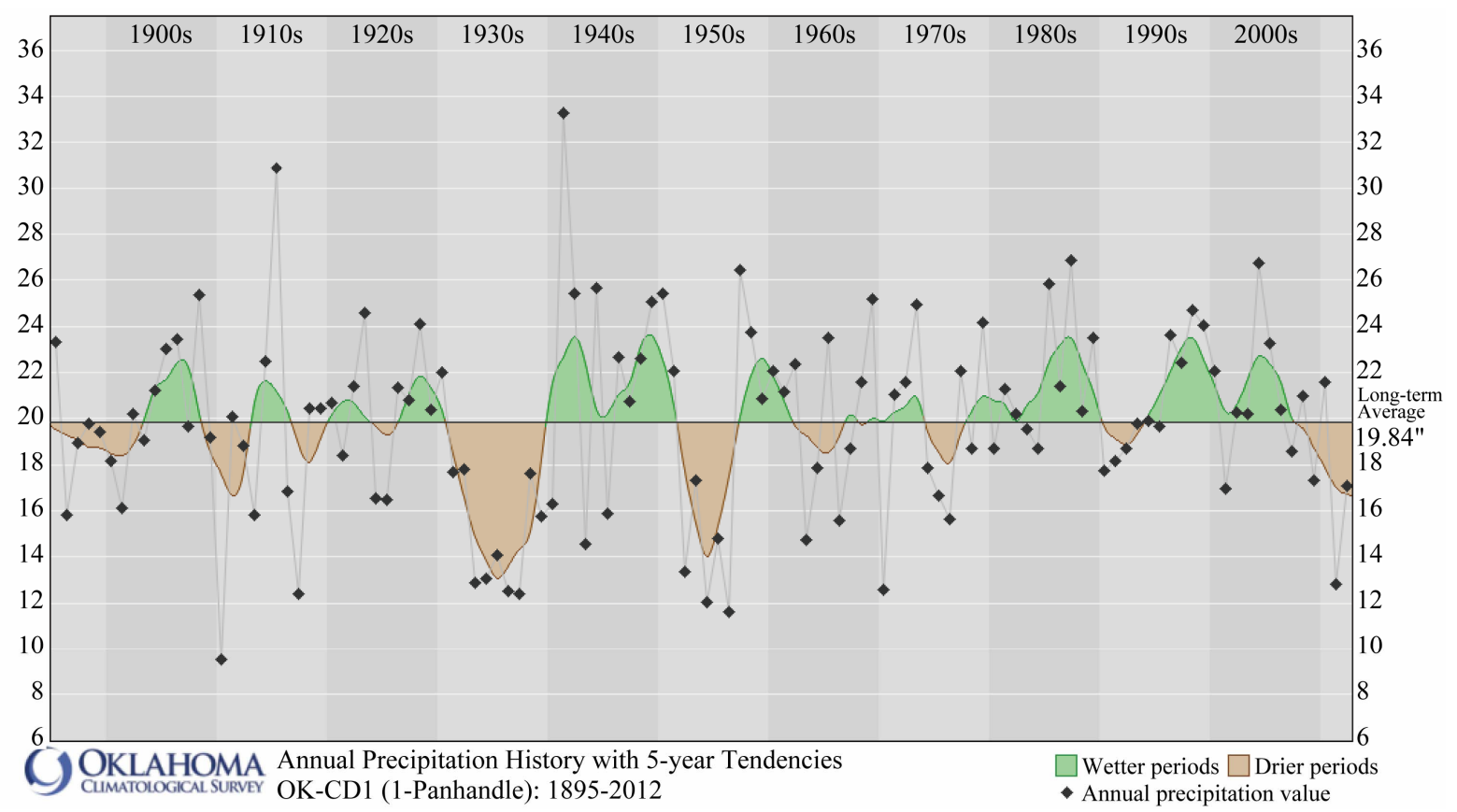

Figure 3. Annual total precipitation (in) within the NOAA Climate Division 1 in Oklahoma (OK-CD1). Periods displayed as brown represent below normal precipitation (drought) while periods displayed as green represent above normal precipitation (pluvials).

Poor farming practices were a major contributor to the Dust Bowl drought of the 1930s and some of these practices continue today. For example, the Great Plains underwent significant overturning of land from natural grassland to irrigated farmland during the 20th century [3]. This practice has increased erosion, which can exacerbate drought conditions. At the same time, population in the Great Plains has increased substantially over recent decades [4-6] and the demand for water resources from the region for agriculture and human consumption has also increased. As the need for water grows, periods with continuous drought conditions, such as 2011-2012, place excessive pressure on not just the individuals who live in the Great Plains, but also those who benefit from the myriad of agricultural products grown across the region. In an increasingly globalized economy, volatility caused by drought in one region affects those in other regions as well as globally. For this reason, understanding the causes and ways to mitigate drought are of paramount importance to those who live in the Great Plains and those who benefit from crops produced there.

Further, there is growing concern that climate change may enhance future drought conditions in the Great Plains, although confidence in this prediction is low [7]. Because of climate change and the complex nature of drought, it is essential that state and local governments prepare drought mitigation and adaptation strategies, such as creating water budgets, implementing sustainable water strategies, and communicating the risks and forecasts of drought. This review paper is focused on the causes and impacts of drought within the Great Plains as related to the continuing need to gather and integrate the 


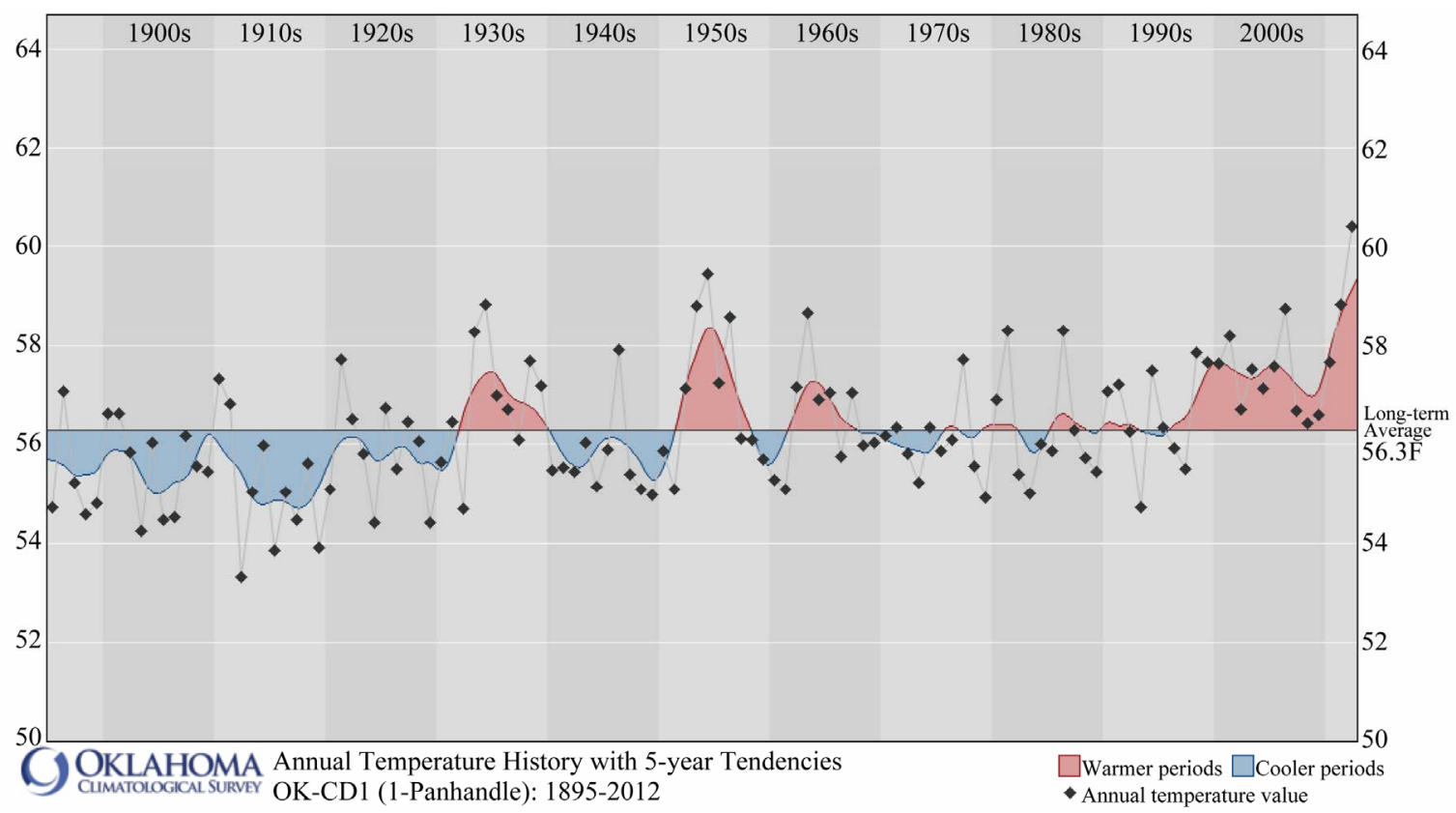

Figure 4. Annual average temperature $\left({ }^{\circ}\right.$ F) within the NOAA Climate Division 1 in Oklahoma (OK-CD1). Red periods represent above normal temperatures while periods displayed as blue represent below normal temperatures.

current knowledge state of the research needed to design such strategies.

\section{Causes of Drought in the Great Plains}

\subsection{Synoptic Drought Conditions}

Subsidence is the sinking of the atmosphere over an area and is perhaps the simplest cause of a lack of rainfall and above normal temperatures as it reduces cloud and precipitation formation. Even so, multiple factors play critical roles in reducing precipitation for extended durations suitable for the development of drought.

Schubert et al. [8] noted that during the Dust Bowl, anomalously high geopotential heights occurred over the middle latitudes and anomalously low geopotential heights over the tropics. Additionally, two upper-level anticyclonic anomalies were present over the Atlantic on either side of the equator with the northern member over the Gulf of Mexico. This acted to suppress moisture return from the Gulf of Mexico to the Great Plains that is normally vital for precipitation there [9]. Brönnimann et al. [10] further noted that the Dust Bowl saw increased mid-tropospheric ridging and a weaker low-level jet. The low-level jet is a moisture transport mechanism from the Gulf of Mexico and Caribbean into the Great Plains that occurs on a diurnal cycle. During the Dust Bowl, the meridional component of the low-level jet was generally weaker than in the wetter early 1940s and the jet did not penetrate as far north. Additionally, thermal structures show stronger stability than normal in the lowest kilometer of the atmosphere during the Dust Bowl, which likely results from the mid-tropospheric ridging and strong subsidence. All of these factors led to a decrease in atmospheric deep convection in the Great Plains which led to the drought [10].

Trenberth et al. [11], studied the 1988 drought which was characterized by high pressure in the North Central United States, a jet stream that was displaced to the north, a largely stationary wave train, and positive feedbacks resulting from anticyclonic conditions. Dong et al. [12] describes the 2006 drought in the Great Plains as having a positive $500 \mathrm{mb}$ height anomaly over the desert southwest and a negative $500 \mathrm{mb}$ height anomaly over the Great Lakes. The resulting mid-tropospheric conditions yielded anomalous northerly flow which limited moisture return over the Great Plains from the Gulf of Mexico.

Additional studies provide a more general description of synoptic conditions that lead to drought in the Great Plains, as opposed to specific examples from historic cases. Namias [13] describes the large scale wind system typical of Great Plains drought as consisting of a deep, warm anticyclone which is periodically fed by dry subsiding tongues of air emanating from westerlies along the northern border of the United States. Conditions such as the displacement or enhancement of Rossby waves upstream, which can affect westerlies over the central United States, have the ability to end or initiate drought. Namias [13] also noted that rapid and long-term drought development had different synoptic conditions. Rapid drought development is often associated with a sudden, persistent ridge that can divert westerlies in the midlatitudes, as is the case in the 1980 drought. Once 
drought is established, land-atmosphere coupling can lead to further long-term development, which will be discussed in greater depth later in this paper. In addition, subsidence to the south of strong upper-level jets or under prevailing northerly components of upper-level flow, is cited as a major factor in enhancing the probability of a drought's occurrence.

A particularly noteworthy feature that is common in the literature on drought in the Great Plains is a mid- to upper-level anticyclone. This feature acts to suppress rainfall because it leads to subsidence, mid-tropospheric warming, and increased low-level static stability [14]. Heat waves, a phenomenon often associated with drought, can also result from positive height anomalies aloft due to subsidence and clear skies [15]. Hot and dry conditions are likely when upper-level positive height anomalies couple with a deep surface low over the Rocky Mountains. This is particularly likely when features persist and soil moisture is already low [16].

\subsection{Teleconnections}

Through teleconnections, sea surface temperatures (SSTs) have an impact on weather and climate patterns and are often referenced in studies regarding drought. However, there is significant uncertainty as to which SST anomalies and atmospheric circulations cause drought or pluvial conditions. Meng and Quiring [17] noted that, "Although El Niño-Southern Oscillation (ENSO) can influence GP [Great Plains] summer precipitation, these influences vary greatly over time and space". Even so, mounting scientific evidence points to the critical role that SST conditions play in drought events.

Seager et al. [18] concluded that SST abnormalities in the Pacific, most likely associated with ENSO events, were a strong driver for droughts and pluvial periods. Schubert et al. [8] agreed that it is primarily the tropical part of Pacific SST anomalies that influence the Great Plains. The Great Plains tend to have above-normal precipitation when the tropical Pacific SSTs are warmer normal, while there is a tendency for drought when the tropical SSTs are colder than normal. In particular, when negative SST anomalies exist in the Pacific, the subtropical jet and intertropical convergence zone (ITCZ) are shifted north, transporting transient eddies that drive descent in the midlatitudes and suppressing precipitation. The Hadley cell is strengthened during negative SSTs, creating descent over the Gulf of Mexico and the southeast US, leading to less moisture transport from the Gulf of Mexico by the low-level jet which further prolongs the drought conditions [18,19]. Further, White et al. [20] discussed how La Niña conditions (cooler than average SSTs across the western equatorial and central/eastern tropical North Pacific Ocean) are correlated with AprilAugust drought. These studies suggest that generaliza- tions can be made regarding what SST patterns and atmospheric circulations cause drought in the Great Plains. Conversely, Englehart and Douglas [14] compared multiregional droughts to Pacific Decadal Oscillation (PDO) and ENSO phases and found that there was no preference for any specific ENSO phase correlated to drought. Though there was no overall trend found between drought and ENSO, it was possible for individual events to be influenced by ENSO related anomalies.

Multi-decadal oscillations seem to have more of a correlation to drought than ENSO [8]. One such oscillation is the Atlantic Multidecadal Oscillation, a 60 - 80 year SST variation. The warm phase of the AMO (warmer temperatures in the North Atlantic Ocean) creates lower precipitation for the central US because it weakens the North Atlantic subtropical high pressure and opposes the low-level jet $[21,22]$. The cold phase of the AMO creates positive precipitation anomalies in the central United States, which can be attributed to a decrease in the moist static stability and enhanced relative vorticity [22]. Nigam et al. [21] used observational data rather than model analyses and found that Atlantic SSTs played the most significant role in forcing the drought of the Dust Bowl summer, Dust Bowl spring, and the 1980s pluvial.

Another teleconnection relevant to drought in the Great Plains is associated with the PDO. Both phases are a factor in causing drought: under positive PDO, drought tends to be associated with lower sea level pressure (SLP) and hotter than normal temperatures over the continent, while under negative PDO, drought tends to be associated with higher SLP and nearly normal temperatures, especially early on in the warm season [14]. White et al. [20] also considered the Quasi-Decadal Oscillation (QDO) and the Interdecadal Oscillation (IDO) and found that both can create secondary droughts in their cool phases in April-August when ENSO is weak. However, strong ENSO activity can break droughts associated with the QDO and IDO.

Studies of particular droughts can also provide insight into drought teleconnection causes. Trenberth et al. [11] found that the 1988 drought was preceded by a strong El Niño in 1987 which created warmer SSTs along the equator and led to large displacements of the major rainproducing convergence zones in the tropics and other atmospheric circulations. These conditions ended by the early spring of 1988 , which is when severe drought rapidly developed in the Great Plains. The drought was attributed to a stationary wavetrain and circulation anomalies that led to positive upper-level height anomalies in the northern Great Plains. More Recently, Hoerling et al. [23] noted that La Niña conditions likely played a critical role in extreme drought conditions that formed during the summer of 2011 over the Southern Great Plains.

Schubert et al. [12] further examined the SST anoma- 
lies during the Dust Bowl and found that they were generally negative in the northern and tropical Pacific, as well as much of the southern Atlantic and Pacific; they were typically positive in the tropical and northern Atlantic, as well as portions of the southern Pacific. These anomalies were less than $0.3^{\circ} \mathrm{C}$ for the most part, except for in the northern Atlantic and off of the Asian coast. The analyses yielded that tropical SSTs had more of an effect on the Dust Bowl than extratropical ones, though extratropical SST anomalies helped to more accurately resolve the region of drought in the Great Plains. It is likely that the atmospheric circulation responses to these SSTs were to create positive geopotential height anomalies in the midlatitudes, as well as upper-level anticyclones in the southern US and lower-level cyclones that were in position to block moisture transport from the Gulf of Mexico. Cook et al. [2] concluded that both the drought periods of the 1930s and 1950s were consistent with coincident cold eastern Pacific SST anomalies and warm Atlantic anomalies further illustrating the complex relationship between intercontinental, terrestrial drought as related to SST patterns through teleconnections.

\subsection{Land-Atmosphere Coupling}

Just as drought can be affected by SSTs and the resulting atmospheric circulations, drought is often enhanced by land-atmosphere coupling (i.e., interactions between the earth's land surface and the atmosphere). Climate transition zones, where strong gradients of temperature, precipitation, and/or other meteorological factors exist over a relatively small distance, are particularly prone to landatmosphere coupling [24]. Such conditions exist in the Great Plains and studies such as Koster et al. [25] have demonstrated that the region yields strong coupling at various spatial and temporal scales during the warmseason.

Soil moisture is the main variable that drives landatmosphere coupling related to drought. Soil that is already dry can enhance the drought by several methods: the dry soil tends to have a lower albedo, higher sensible heat flux, lower latent heat flux, warming surface temperatures, reduced vegetation and evapotranspiration, and decreased precipitation $[11,25,26]$. These mechanisms create positive feedback loops, making drought selfperpetuating [11].

Soil moisture was at an extreme minimum during the Dust Bowl of the 1930s and Cook et al. [27] noted that the amount of dust emission in 1935 alone was estimated at millions of metric tons of topsoil were subject to wind erosion. Because dust reduced the net radiation that at the surface, it further reduced evaporation rates and thus precipitation. Their study demonstrated that the inclusion of dust loading versus SST forcing alone were better able to reproduce the severity of the drought and the region af- fected by drought. This implies that record-setting dust loading worked as a positive feedback mechanism to the drought, and is an extreme version of land-atmosphere coupling.

Long-term (1930-2000) simulations made by an atmospheric general circulation model as part of the National Aeronautics and Space Administration (NASA) Seasonal-to-Interannual Prediction Project found that only about $1 / 3$ of short-term (6-year) rainfall variance in the Great Plains is based on SST forcing; the rest is mainly based on interactions with soil moisture [8]. Hong and Kalnay [26] demonstrated the importance of soil moisture in their simulations, showing that during the 1998 drought, higher soil moisture would have resulted in increased precipitation in the spring while reduced soil moisture would have decreased precipitation in the summer and fall and caused a positive feedback toward more drought-like conditions. Meng and Quiring [17] further demonstrated that when spring soil moisture is above normal in the northern Great Plains, summer precipitation tends to be above normal and a trend toward pluvial periods instead of drought.

On the whole, land-atmosphere coupling is a significant process in drought in the Great Plains, particularly in its perpetuation. Further, land-atmosphere coupling often plays a significant role at a more local and smaller time scales, while teleconnection and synoptic causes tend to be the major forcings of drought on a larger and longer time scales $[9,25]$. Moreover, droughts are often initially caused by teleconnections and maintained by land-atmosphere interactions such as the absence of soil moisture, which can create feedback loops $[11,26]$.

\subsection{Anthropogenic Causes}

Because drought refers to a lack of water to supply to a particular demand, an increase in demand would be comparable to a decrease in supply. The population of the Great Plains has been growing in recent decades and more people require increasing amounts of water, which means drought can occur more often in the presence of humans and competing demands for agriculture, industry, and consumptive use [28].

Perhaps the most obvious example of the actions of humans leading to a drought related disaster is the 1930's Dust Bowl. The poor land use practices of farmers in the Great Plains in the early 20th century can be to blame for the initiation and worsening of the drought situation [29]. Specifically, in the Dust Bowl, drought-resistant prairie grass was replaced with drought-sensitive wheat. When the wheat failed, it left barren, eroded soil exposed, which had feedbacks that worked to enhance the drought. Removing vegetation severely reduces evapotranspiration, leading to enhanced surface temperatures [27]. When human induced drought mechanisms work in tandem 
with synoptic features, teleconnections, and land-atmosphere coupling, drought conditions can rapidly intensify and persist for extended periods.

\section{Impacts of Drought in the Great Plains}

Droughts are most often characterized by the impacts they produce which often cover a multitude of sectors. One of the most significant impacts of drought is focused on the agricultural industry. In 1983, the grain production in the Great Plains of the United States accounted for $12 \%-15 \%$ of the world's total production and $60 \%$ $65 \%$ of grain production was used in the United States [30]. However, variable weather patterns can cause wheat production to either flourish or be devastated. Currently, while worldwide grain production has increased, the US production has remained nearly unchanged. As a result, grain production in the US currently accounts for approximately $10 \%$ of the total world production [31]. Even so, reduction to grain production in the Great Plains of the US due to drought has significant impact on the world's grain capacity and overall food availability both in the US and worldwide. Further, food nutritional content is another consequence of drought. When a drought occurs and agricultural production suffers due to reduced crop yields, the overall quality of the plant, and product due to poor growing conditions. As such, the product can have less nutritional value than the product that was grown and harvested in conditions optimal for normal growth [32].

A second critical impact of prolonged drought in the Great Plains is the availability of surface and ground water. In particular, numerous reservoirs have been constructed across the region for a variety of applications [33]. However, competing needs and depletion of ground water for agriculture when combined with drought have led to significant declines in lake levels and streamflow throughout the Great Plains [34,35]. Because consumptive use is also dependent upon the capacity and quality of the water in the large reservoirs, long-term reductions can significantly impact major, rapidly growing population centers across and adjacent to the Great Plains such as the Dallas-Fort Worth Metroplex.

As drought persists, agriculture is impacted, and water resources for human consumption and recreation become stressed and limited. As a result, large economic impacts can occur. A climatological study of extreme weather and climate events from 1980-2003 by Ross and Lott [28] demonstrated that the monetary losses from the 1988 drought event alone were estimated at $\$ 61.6$ billion (\$78.6 billion USA adjusted to 2012). Much of this loss can be attributed to the impacts sustained by agriculture and related industries. Further, of all the extreme weather events that took place between 1980 and 2003, the 10 major droughts/heat waves that occurred accounted for
$\$ 147$ billion, or $42 \%$ of the total weather-related loss. Of those 10 major droughts/heat waves, six occurred in the Great Plains and accounted for $\$ 131.7$ billion, or $91 \%$ of the total monetary losses from drought. Such losses were subsequently passed on to the consumers as price increases for staple food products, and for the severe drought of 1988, consumers saw products including cereals and breads rise in price by nearly $20 \%$ [36].

The impacts of drought in the Great Plains impact human health as well. When drought occurs, water levels in the affected region drop to below normal levels and cause the body of water to heat faster and reach higher than normal temperature values. Such conditions lower dissolved oxygen levels and yield increases in disease and bacteria growth within the water. As such, humans that come in contact with this untreated water, such as people involved in outdoor recreational water activities, have a heightened risk of becoming infected [32]. During the recent, intense drought across the southern portion of the Great Plains in 2011 [23], numerous outbreaks of toxic blue-green algae occurred in ponds, lakes, and reservoirs across the region. Additionally, during drought conditions, soil and the atmospheric conditions are dry leading to increased suspension of dust and particulates. Increased particulate matter can aggravate the lungs and airways, potentially causing asthma and respiratory infections such as bronchitis and pneumonia [23]. Perhaps the most iconic impact of the Dust Bowl drought period of the 1930's was the human suffering caused by the ingestion of dust and subsequent dust pneumonia. Such health impacts can eventually lead to death. In the case of the severe drought of 1988 in the Great Plains, an estimated $5000-10,000$ deaths were attributed to the drought conditions including those caused by severe heat, which can be exacerbated by high sensible heat fluxes that often occur during drought periods [28]. Unfortunately, because the frequency and duration of heat waves may increase across the region [15], the public health challenge will persist in an increasingly growing population base across the Great Plains.

\section{Termination of Drought}

For drought to end, precipitation is required to remove not only the precipitation deficit but also to alleviate agricultural drought and restore soil moisture, streams, and lakes to near normal conditions. In any given region, the amount of precipitation will vary in as related to the annual precipitation and soil moisture cycles. Karl et al. [37] noted that drought is assumed to have ended when Palmer Drought Severity Index (PDSI) is equal to -0.5 . As an example for the Great Plains, to end the devastating droughts of the 1930's and 1950's in South-Central Nebraska, a total of seven times the average 2-month precipitation total would have been needed to end the 
droughts during the winter months, and three times the average 2-month precipitation total would have been needed during spring and early summer. This significant difference is because in drier months such as winter, soil moisture conditions are lower to begin with and so less precipitation is needed to return conditions to normal. Whereas for a drought in the wet season, soil moisture content is usually higher and so more precipitation is required for conditions to recover to their normal levels [37]. Unfortunately, within the Great Plains region, due to the great deficits of precipitation that need to be overcome, drought tends to persist for a greater length of time than in any other part of the US.

Even so, specific meteorological events can alleviate the impacts of drought. For example, landfalling tropical systems can force plumes of deep tropical moisture and precipitation into the region. Not only does the heavy precipitation reduce the precipitation deficits, it can disrupt land-atmosphere coupling that has perpetuated a cascading affect of drying the land-surface and overlying atmosphere. A landfalling hurricane has the potential to provide so much precipitation that it can independently terminate even a multiyear drought. While somewhat rare in the Great Plains region, such events have the potential to alleviate drought conditions. Maxwell et al. [38] found that tropical cyclones were more likely to dramatically improve drought conditions when the North Atlantic Oscillation (NAO) was in its negative phase compared to its positive phase.

\section{Predicability and Future of Drought in the Great Plains}

While great strides have been made in determining the causes of drought, utilizing this information to determine a confident forecast for the future of drought in the Great Plains has been less successful. Indeed, the most prominent global climate forecast authority, the Intergovernmental Panel on Climate Change (IPCC), has stated that it has low confidence in its forecast of drier conditions and increased drought in the Great Plains [7]. The importance of trying to predict future climate change is especially important considering the rapid depletion of the Ogallala Aquifer, the chief natural irrigation source in the Great Plains [39]. Numerous studies have been conducted using global circulation models to determine whether drought will increase in the Great Plains, and they attempt to explain the difficulty of making broad statements on the future climate in the Great Plains $[40,41]$.

A major source of error in climate predictions is the sensitivity and accuracy of drought indicators [40-42]. When the PDSI is used to determine future drought, it has been found to overstate drought severity because it is hyper-sensitive to surface temperature changes [40].
Compounding the surface temperature sensitivity problem, the PDSI does not take biological feedbacks into account. Soil moisture is another important index because if dry conditions are already present, then a given change in soil moisture will have a larger impact on evaporation than if moist conditions were initially present [41]. Including multiple indices such as the PDSI, the Standardized Precipitation Index (SPI), and those considering soil moisture anomalies, total precipitation, and evapotranspiration feedbacks, could make for more accurate climate predictions [40-42].

The future of drought in the Great Plains is likely tied closely to tropical sea surface temperatures (SSTs) in the Pacific and Atlantic, which are both expected to increase throughout the next century $[8,15,18,41,43]$. Considering that many of the great droughts of the 20th century ended following the onset of El Nino, understanding the SST oscillation patterns, especially ENSO, is vital for predicting not only the onset of drought, but the end of drought [41-43].

Atmospheric warming due to increases in greenhouse gases may increase the frequency and severity of drought in the Great Plains [15]. Most heat waves in the Great Plains are caused by a positive, semi-stationary $500 \mathrm{mb}$ height anomaly that sets up in the north-central Great Plains $[15,16,44]$. Subsidence associated with this anomaly creates drying and warming and can also cut off the flow of moisture from the Gulf of Mexico [15,44]. Parallel climate model results indicate that positive $500 \mathrm{mb}$ height anomalies are more likely to occur over the Great Plains as surface temperatures increase, thus increasing the risk of severe drought and heat wave events [15].

\section{Concluding Remarks}

Our understanding of the causes of drought in the Great Plains has progressed a great deal throughout the 20th and early 21 st centuries. This progress is due, in part, to better observations from remote sensors, such as automated weather stations and satellites. Our ability to use this data in numerical models has yielded a better understanding of the physical processes which contribute to drought. Many of these physical processes such as soil evaporation and global atmospheric circulation cause it to remain difficult to physically model weeks, let alone months or years, in advance. This difficulty has made prediction of drought challenging, and many research methods have evolved to make progress in this area. Advancements in numerical models and data assimilation techniques will likely improve our ability to forecast droughts.

Currently, the best option to predict drought still lies in the ability to forecast conditions commonly associated with drought. The current state of research is in agreement that strong, persistent high pressures associated 
with subsidence and ridging in the jet stream over the Great Plains are the most common conditions contributing to drought. In addition, the importance of moisture from the Gulf of Mexico and the strength of the lowlevel jet, which brings moisture northward into the Great Plains, mentioned throughout the scientific literature are listed as key contributors. Less clear are how teleconnections with SST anomalies such as the El Niño-Southern Oscillation or the Pacific Decadal Oscillation affect conditions commonly associated with drought in the Great Plains. Strong evidence suggests that sea surface temperatures play an important role in controlling atmospheric circulation, however, methods vary considerably in determining the exact impacts of SSTs. Nevertheless, strides are being made in this area, but limited data sets still add to the uncertainties.

Climate change and its relationship with drought in the Great Plains is still a nascent area of research. The IPCC 2007 [7] report still has low confidence in whether or not the frequency of droughts will increase in the Great Plains. However, research across a broad spectrum of disciplines continues to study potential impacts of a warming Plains region and more robust conclusions are likely in the near future. Regardless of whether or not droughts become worse in the future, mitigation strategies such as water budgeting and planning will greatly increase the likelihood of muting drought impacts when droughts occur.

Fundamentally, drought still suffers from a lack of definition. Attempts to define drought from a meteorological, agricultural, or hydrological point of view are quite useful, and it appears that research has not been hindered by these many definitions. The public's understanding of what drought means is still a concern. For example, few individuals are probably aware that the past 30 years are typically used to define the climatology of normal temperatures and precipitation for a region. Because the last 30 years could have experienced significant pluvial conditions, as is the case throughout the Great Plains, it stands to reason that the past 30 years may not be representative of future precipitation patterns and drought conditions.

Above all, drought is a societal problem. Drought has become a growing problem within the Great Plains as population growth over past decades has increased. This is especially true in the Southern Great Plains where a growing megapolitan includes the major metropolitan areas of Houston, San Antonio, Austin, Dallas-Fort Worth, and Oklahoma City [4]; each of these urban areas grew by double-digit percentage increases during the last decade (e.g., Houston: 26.1\%; San Antonio: 21.1\%; Austin: $36.4 \%$, Dallas-Fort Worth: 24.9\%; Oklahoma City: $12.0 \%$; [5,6]). Higher population leads to more stress on water supplies, which can, by itself, create or exacerbate drought conditions. How communities prepare and manage water supplies will likely contribute to future drought impacts across the region. Further, prediction of drought remains difficult, but our overall understanding of drought has increased dramatically throughout the past century, and this knowledge trend is likely to continue. As such, research is still needed a) to focus on drought across the Great Plains, b) to predict and detect drought events at all spatial and temporal scales, and c) to plan and prepare for the socioeconomic impacts of drought.

\section{Acknowledgements}

The authors would like to thank Michael Cartwright, Wava Denito, Zachariah Elliot, Jack McLean, Koby Pascual, Daniela Spade, and Jonathan Wille for knowledge contributions to the review. Funding for this work was provided, in part, by a USDA AFRI grant to better understand vulnerability and resilience of Southern Great Plains beef in an environment of increased climate variability, dynamic land-use and fluctuating markets.

\section{REFERENCES}

[1] D. Burnette and D. Stahle, "Historical Perspective on the Dust Bowl Drought in the Central United States," Climatic Change, Vol. 116, No. 3-4, 2013, pp. 479-494. doi:10.1007/s10584-012-0525-2

[2] B. Cook, R. Seager and R. Miller, "Atmospheric Circulation Anomalies during Two Persistent North American Droughts: 1932-1939 and 1948-1957," Climate Dynamics, Vol. 36, No. 11-12, 2011, pp. 2339-2355. doi:10.1007/s00382-010-0807-1

[3] R. Mahmood, S. A. Foster, T. Keeling, K. G. Hubbard, C. Carlson and R. Leeper, "Impacts of Irrigation on 20th Century Temperature in the Northern Great Plains," Global and Planetary Change, Vol. 54, No. 1-2, 2006, pp. 1-18. doi:10.1016/j.gloplacha.2005.10.004

[4] N. B. Grimm, D. Foster, P. Groffman, J. M. Grove, C. S. Hopkinson, K. J. Nadelhoffer, D. E Pataki and D. P. C. Peters, "The Changing Landscape: Ecosystem Responses to (Urbanization and Pollution across Climatic and Societal Gradients," Frontiers in Ecology and the Environment, Vol. 6, No. 5, 2008, pp. 264-272. doi: $10.1890 / 070147$

[5] United States Census Bureau, "Population Distribution and Change: 2000-2010".

http://www.census.gov/prod/cen2010/briefs/c2010br-01.p df

[6] United States Census Bureau, "2010 Census Urban and Rural Classification and Urban Area Criteria".

http://www.census.gov/geo/reference/ua/urban-rural-2010 .html

[7] S. Solomon, D. Qin, M. Manning, Z. Chen, M. Marquis, K. B. Averyt, M. Tignor and H. L. Miller, "Climate Change 2007-The Physical Science Basis," Cambridge University Press, Cambridge, 2007. 
[8] S. D. Schubert, M. J. Suarez, P. J. Pegion, R. D. Koster, and J. T. Bacmeister, "Causes of Long-Term Drought in the U.S. Great Plains," Journal of Climate, Vol. 17, No. 3, 2004, pp. 485-503.

doi: $10.1175 / 1520-0442(2004) 017<0485:$ COLDIT $>2.0 . C$ $\underline{\mathrm{O} ; 2}$

[9] S. D. Schubert, M. J. Suarez, P. J. Pegion, R. D. Koster and J. T. Bacmeister, "On the Cause of the 1930's Dust Bowl," Science, Vol. 303, No. 5665, 2004, pp. 1855-1859. doi:10.1126/science. 1095048

[10] S. Brönnimann, A. Stickler, T. Griesser, T. Ewen, A. N. Grant, A. M. Fischer, M. Schraner, T. Peter, E. Rozanov and T. Ross, "Exceptional Atmospheric Circulation during the 'Dust Bowl'," Geophysical Research Letters, Vol. 36, No. 8, 2009, Article ID: L08802. doi:10.1029/2009GL037612

[11] K. E. Trenberth, G. W. Branstator and P. A. Arkin, "Origins of the 1988 North American Drought," Science, Vol. 242, No. 4886, 1998, pp. 1640-1645. doi:10.1126/science. 242.4886 .1640

[12] X. Q. Dong, B. Xi, A. Kennedy, Z. Feng, J. K. Entin, P. R. Houser, R. A. Schiffer, T. L'Ecuyer, W. S. Olson, K.-L. Hsu, W. T. Liu, B. Lin, Y. Deng and T. Jiang, "Investigation of the 2006 Drought and 2007 Flood Extremes at the Southern Great Plains through an Integrative Analysis of Observations," Journal of Geophysical Research: Atmospheres, Vol. 116, No. D3, 2011, Article ID: D03204. doi:10.1029/2010JD014776

[13] J. Namias, "Some Causes of United States Drought," Journal of Climate and Applied Meteorology, Vol. 22, No. 1, 1983, pp. 30-39. doi:10.1175/1520-0450(1983)022<0030:SCOUSD $>2.0 . \mathrm{C}$ $\underline{\mathrm{O} ; 2}$

[14] P. J. Englehart and A. V. Douglas, "Assessing Warm Season Drought Episodes in the Central United States," Journal of Climate, Vol. 16, No. 11, 2003, pp. 1831-1842. doi:10.1175/1520-0442(2003)016<1831:AWSDEI $>2.0 . C$ $\underline{\mathrm{O} ; 2}$

[15] G. A. Meehl and C. Tebaldi, "More Intense, More Frequent, and Longer Lasting Heat Waves in the 21st Century," Science, Vol. 305, No. 5686, 2004, pp. 994-997.

[16] F.-C. Chang and J. M. Wallace, "Meteorological Conditions during Heat Waves and Droughts in the United States Great Plains," Monthly Weather Review, Vol. 115, No. 7, 1987, pp. 1253-1269. doi:10.1175/1520-0493(1987)115<1253:MCDHWA >2.0. $\underline{\mathrm{CO} ; 2}$

[17] L. Meng and S. M. Quiring, "Observational Relationship of Sea Surface Temperatures and Precedent Soil Moisture with Summer Precipitation in the U.S. Great Plains," International Journal of Climatology, Vol. 30, No. 6, 2010, pp. 884-889.

[18] R. Seager, Y. Kushnir, C. Herweijer, N. Naik and J. Velez, "Modeling of Tropical Forcing of Persistent Droughts and Pluvials over Western North America: 1856-2000," Journal of Climate, Vol. 18, No. 19, 2005, pp. 4065-4088. doi:10.1175/JCLI3522.1

[19] K. C. Mo, J. N. Paegle and R. W. Higgins, "Atmospheric Processes Associated with Summer Floods and Droughts in the Central United States," Journal of Climate, Vol. 10, No. 12, 1997, pp. 3028-3046. doi:10.1175/1520-0442(1997)010<3028:APAWSF $>2.0 . C$ $\underline{\mathrm{O} ; 2}$

[20] W. B. White, A. Gershunov and J. Annis, "Climatic Influences on Midwest Drought during the Twentieth Century," Journal of Climate, Vol. 21, No. 3, 2008, pp. 517531. doi:10.1175/2007JCLI1465.1

[21] S. Nigam, B. Guan and A. Ruiz-Barradas, "Key Role of the Atlantic Multidecadal Oscillation in 20th Century Drought and Wet Periods over the Great Plains," Geophysical Research Letters, Vol. 38, No. 16, 2011. doi:10.1029/2011GL048650

[22] M. C. Veres and Q. Hu, "AMO-Forced Regional Processes Affecting Summertime Precipitation Variations in the Central United States," Journal of Climate, Vol. 26, No. 1, 2013, pp. 276-290. doi:10.1175/JCLI-D-11-00670.1

[23] M. Hoerling, A. Kumar, R. Dole, J. W. Nielsen-Gammon, J. Eischeid, J. Perlwitz, X.-W. Quan, T. Zhang, P. Pegion and M. Chen, "Anatomy of an Extreme Event," Journal of Climate, Vol. 26, No. 9, 2012, pp. 2811-2832. doi:10.1175/JCLI-D-12-00270.1

[24] S. I. Seneviratne, D. Lüthi, M. Litschi and C. Schär, "LandAtmosphere Coupling and Climate Change in Europe," Nature, Vol. 443, No. 7108, 2006, pp. 205-209. doi:10.1038/nature05095

[25] R. D. Koster, P. A. Dirmeyer, Z. Guo, G. Bonan, E. Chan, P. Cox, C. T. Gordon, S. Kanae, E. Kowalczyk, D. Lawrence, P. Liu, C.-H. Lu, S. Malyshev, B. McAvaney, K. E. Mitchell, D. Mocko, T. Oki, K. Oleson, A. Pitman, Y. C. Sud, C. M. Taylor, D. Verseghy, R. Vasic, Y. Xue and T. Yamada, "Regions of Strong Coupling between Soil Moisture and Precipitation," Science, Vol. 305, No. 5687, 2004, pp. 1138-1140. doi:10.1126/science. 1100217

[26] S. Y. Hong and E. Kalnay, "Role of Sea Surface Temperature and Soil-Moisture Feedback in the 1998 Oklahoma-Texas Drought," Nature, Vol. 408, No. 6814, 2000, pp. 842-844. doi: $10.1038 / 35048548$

[27] B. I. Cook, R. L. Miller and R. Seager, "Dust and Sea Surface Temperature Forcing of the 1930s 'Dust Bowl' Drought," Geophysical Research Letters, Vol. 35, No. 8, 2008. doi:10.1029/2008GL033486

[28] T. Ross and N. Lott, "A Climatology of 1980-2003 Extreme Weather and Climate Events," National Climatic Data Center Technical Report 2003-01, 14 p.

[29] D. A. Wilhite and M. H. Glantz, "Understanding: The Drought Phenomenon: The Role of Definitions," Water International, Vol. 10, No. 3, 1985, pp. 111-120. doi: $10.1080 / 02508068508686328$

[30] A. D. Hecht, "Drought in the Great Plains: History of Societal Response," Journal of Climate, Vol. 22, No. 1, 1983, pp. 51-56.

[31] United States Department of Agriculture, "Table 4-World and U.S. Wheat Production, Exports and Ending Stocks". http://www.ers.usda.gov/data-products/wheat-data.aspx\#. UdIfDhYdpFs

[32] Centers for Disease Control and Prevention, "When 
Every Drop Counts".

http://www.cdc.gov/nceh/ehs/Docs/When_Every_Drop_ Counts.pdf

[33] K. H. Costigan and M. D. Daniels, "Damming the Prairie: Human Alteration of Great Plains River Regimes," Journal of Hydrology, Vol. 444-445, 2012, pp. 90-99. doi:10.1016/j.jhydrol.2012.04.008

[34] T. H. Brikowski, "Doomed Reservoirs in Kansas, USA? Climate Change and Groundwater Mining on the Great Plains Lead to Unsustainable Surface Water Storage," Journal of Hydrology, Vol. 354, No. 1-4, 2008, pp. 90101. doi:10.1016/j.jhydrol.2008.02.020

[35] F. Wen and X. Chen, "Evaluation of the Impact of Groundwater Irrigation on Streamflow in Nebraska," Journal of Hydrology, Vol. 327, No. 3-4, 2006, pp. 603-617. doi:10.1016/j.jhydrol.2005.12.016

[36] J. Opie, "The Drought of 1988, the Global Warming Experiment, and Its Challenge to Irrigation in the Old Dust Bowl Region," Agricultural History, Vol. 66, No. 2, 1992, pp. 279-306.

[37] T. R. Karl, F. Quinlan and D. S. Ezell, "Drought Termination and Amelioration: Its Climatological Probability," Journal of Climate and Applied Meteorology, Vol. 26, No. 9, 1987, pp. 1198-1209. doi:10.1175/1520-0450(1987)026<1198:DTAAIC $>2.0 . C$ $\underline{\mathrm{O} ; 2}$

[38] J. T. Maxwell, P. T. Soulé, J. T. Ortegren and P. A. Knapp, "Drought-Busting Tropical Cyclones in the Southeastern Atlantic United States: 1950-2008," Annals of the Association of American Geographers, Vol. 102, No. 2,
2012, pp. 259-275. doi:10.1080/00045608.2011.596377

[39] T. R. Karl, J. M. Melillo, T. C. Peterson and S. J. Hassol, "Global Climate Change Impacts in the United States," Cambridge University Press, Cambridge, 2009.

[40] M. P. Hoerling, J. K. Eischeid, X. W. Quan, H. F. Diaz, R. S. Webb, R. M. Dole and D. R. Easterling, "Is a Transition to Semipermanent Drought Conditions Imminent in the U.S. Great Plains?” Journal of Climate, Vol. 25, No. 24, 2012, pp. 8380-8386. doi:10.1175/JCLI-D-12-00449.1

[41] S. D. Schubert, M. J. Suarez, P. J. Pegion, R. D. Koster, and J. T. Bacmeister, "Potential Predictability of LongTerm Drought and Pluvial Conditions in the U.S. Great Plains," Journal of Climate, Vol. 21, No. 4, 2008, pp. 802-816. doi:10.1175/2007JCLI1741.1

[42] K. Strzepek, G. Yohe, J. Neumann and B. Boehlert, "Characterizing Changes in Drought Risk for the United States from Climate Change," Environmental Research Letters, Vol. 5, No. 4, 2010, Article ID: 044012. doi:10.1088/1748-9326/5/4/044012

[43] S. J. Weaver, "Factors Associated with Decadal Variability in Great Plains Summertime Surface Temperatures," Journal of Climate, Vol. 26, No. 1, 2013, pp. 343-350. doi:10.1175/JCLI-D-11-00713.1

[44] F. C. Chang and E. A. Smith, "Hydrological and Dynamical Characteristics of Summertime Droughts over U.S. Great Plains," Journal of Climate, Vol. 14, No. 10, 2001, pp. 2296-2316. doi:10.1175/1520-0442(2001)014<2296:HADCOS $>2.0 . C$ $\underline{\mathrm{O} ; 2}$ 